\title{
On being a religious education teacher: A reflection on discipleship identity
}

Canete, Jonathan James O. $\triangle$

De La Salle University, Manila, Philippines (ncanete976@gmail.com)

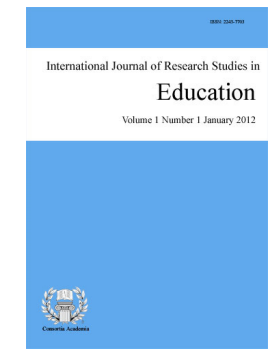

Accepted: 23 January 2022 Online ISSN: $2243-7711$

OPEN ACCESS

\section{Abstract}

The study determines the perception of 99 religious education teachers on their identity as religion teachers using Qualitative methods in data gathering. The researcher asked series of open-ended questions, formulated for a class by Dr. Carolina Dionco, to the respondents about their understanding of what a religious education teacher is all about, what are the challenges and difficulties of being a religion teacher, and the possible intervention in addressing the identified problems. Upon close examination and inductively interpret the responses, three categories were determined to systematically capture the essence of the responses - vocation, rootedness, and formation. The respondents have a strong conviction that being a religious education teacher is a vocation, a calling from God to proclaim the Gospel to the learners. Moreover, that vocation should take its root with the one who calls that is no other than God in the person of Christ. However, such vocation is not without any challenges from the pedagogical aspect of teaching the faith down to the spirituality of the educator, that is why professional and spiritual formation is necessary. The categories were appropriated with the Discipleship Process Framework by Lewis to systematize the relationship of each category together with the hopes of coming up with a new way of understanding what does it mean to be a religion teacher. The appropriation has resulted to the formation of the Discipleship Identity of Religious Educators Framework (DIREF) which understands religious education as a discipleship process, and the identity of religion teachers as a discipleship identity.

Keywords: discipleship, identity, reflection, religious education, teacher 


\section{On being a religious education teacher: A reflection on discipleship identity}

\section{Introduction}

Being an educator in itself is a noble task for educators are deputized by the nature of their profession to serve not just a mere dispenser of knowledge, but more importantly as someone who would proactively guide the growth of children as they: “(a) acquire the skills necessary for gaining knowledge and understandings; (b) develop an understanding of themselves, the world around them, and their place in that world; (c) develop the understandings and relationships which will form the basis for their actions, reactions and interactions in the world in which they will live as adults" (Nations, 1962). In other words, an educator's role has something to do with not just imparting information, theories or concepts, and knowledge that would enhance cognition but also the development of the learner's other intellectual competencies. While there is a predominant type of intelligence a person has, the development of the other type of intelligence enables the person to be intellectually competent in a given context (Marenus, 2020) especially the arduous context of the 21 st century. The 21st century context demands flexibility among learners especially in its fast-pacing, highly globalized and digitalized picturesque - developing the 21 st century learning skills, life skills, and literacy skills (Buckle, 2021). Therefore, competitiveness in the current social setting has something to do basically with the integral development of human intellectual competencies as described by Howard Gardner. The 21st century learning skills are the specifications of Garner's concept of multiple intelligences or intellectual competencies. Moreover, while an individual is encouraged to master a certain intelligence or skills that one excels with, the 21st century social setting requires one to develop the other intellectual competencies in order to be competitive in this kind of society.

Therefore, for students to be competitive and to be at par with the current social milieu, educators should be more than just mere instructors of knowledge, but facilitators of meaningful learning and self-discovery allowing the learners to (1) ascertain their own intellectual and practical capabilities, and (2) recognize not just their own worth but also the invaluable worth of others in the spirit of collaborative work. The teacher's work in the $21 \mathrm{st}$ century "has become more complex with high levels of accountability, increased bureaucratic responsibilities, maintaining a high-level of professionalism without compromising, requiring well-developed social and emotional skills, and have an interactive of pedagogical style in teaching to successfully engage and motivate students" (Crosswell, 2017, p. 416). It is out of these complexities that the Church recognizes the teaching profession as a vocation that demands "special qualities of mind and heart, very careful preparation, and continuing g readiness to renew and to adapt" (Paul VI, 1965). In other words, the vocation to educating the young has something to do with having a clear understanding of one's own role as an educator as well as the proper disposition in manifesting such role together with an adequate knowledge on the appropriate pedagogical instruction that students need to enable a meaning learning atmosphere. Continuous formation of educators is deemed necessary in order to better equip with the crucial means in teaching students in the 21 st century social setting. It is in this thought that the Church looks at the teaching profession not as profession per se nor as a job, but as a vocation for the formation that they will bring to the young depends on the formation that they themselves had received. If being an educator, in the general sense of the term, is already arduous because of the requisites what more the requirements of being a religious education teacher. The Church in the Declaration on Christian Education (Gravissimum Educationis) made mention that religion teacher should have an adequate understanding that their profession calls for not only having mastery over the subject matter, nor having a profound awareness both in the secular and religious knowledge or eloquence in different pedagogical skills in "keeping with the findings of the contemporary world, but more importantly such profession is a vocation of bearing witness to Christ, the unique Teacher" (Paul VI, 1965).

Being a religious education teacher is way of life patterned after the life of Christ, the Teacher par 
On being a religious education teacher: A reflection on discipleship identity

excellence. Therefore, religious education is not just a simple academic subject governed by immaterial and intellectual principles, nor a kind of academic subject that has nothing to do with a person's life particularly the life of both teachers and learners, rather religious education (in the Christian sense) is one of the various ways in proclaiming the Gospel - the life and person of Jesus to the students. In this regard, a religious education teacher must be a credible witness of the faith in Christ to enable effective learning of the faith, and an empowering encounter with the subject matter who is Jesus himself (Paul VI, 1975). Therefore, in order to teach effectively the subject, and in order to proclaim the person of Christ to different types of learners without being incursive on the way they experience the divine, religious education teachers must look and consider the subject as a way of life not just a mere academic subject that they need to teach and that students in Catholic Schools must take as part of their formation. The Church is very clear when she mentioned that the success of proclaiming the message of Christ in the classroom setting (through religious education) depends on the creative pedagogic styles of teachers which highly depends on bearing witness to Christ both in words and in deeds (Sacred Congregation for Catholic Education, 1977). If educators in other disciplines needed to equip themselves with the necessary knowledge in order to cultivate the 21 st century learning skills and stimulate the intellectual competencies among learners, the fundamental requirement for religious education teachers to teach the faith and proclaim the Gospel is by configuring their own images to the image of Christ - witnessing to the very image where their own images where configured. It is by taking up the image of Christ upon the religious education teacher could he/she effectively teach the faith, and more importantly could the learners tangibly and meaningfully encounter the person of Christ. Out if this meaning encounter with the person of Jesus visibly seen in the witnessing prowess of the religious education teacher.

However, even if the Church is clear as to the identity of a religious education teacher mentioned above, the problem here is how clear the understanding of religious education teachers on their role and identity as religion teachers? Do they have the real grasp of their role as religious education teachers? In what way do they perceive and understand their role? What could be the different challenges that they encounter in being educators of the faith, and possible interventions? This study, therefore, aims at knowing the perception of religious education teachers regarding their work, as well as the challenges that comes along the way. On the other hand, the author will try to understand the different responses by framing them into categories and by appropriating them to the Discipleship Process Framework of Dr. Casey Lewis which would leading to the formation of an identity framework for religious education teachers. The framework aims to illustrate the religious education professional not only as a mere profession, but more importantly as a vocation to discipleship rooted in God - the one who inspires and calls persons to be religious educators. This study, likewise, have asked the respondents the probable intervention they have in mind in addressing the challenges they encounter as religious/ values education teachers. These responses would be the basis for a proposed activities or programs which would help other religious education teachers address their own challenges or difficulties in their teaching ministry.

\section{Methodology}

Since the nature of this study is qualitative for the data collected from the respondents were not numerically driven, but instead drawn from the wellspring of their lived experiences and personal perspective as religious education teachers (Denzin \& Lincoln, 2017), open-ended questions were formulated and were presented virtually to the respondents in a form of a survey using Google Forms. In making sense of the gathered information from the respondents and in describing their experiences, the inductive method of interpretation has been employed - where the analysis starts first from the particular experiences of the respondents, then the discovered patterns, themes, and inter-relationships are explored even further by already established principles (Prince \& Felder, 2007). Hence, the responses of the respondents' perception on their profession as religion teachers would be processed and analyzed using the lenses of the already established principles, in this case the concept of discipleship of Lewis in order to come up with a framework and idea that the identity of religious education teacher is an identity of discipleship. 


\section{The Respondents and Informed Consent}

This section of the study shows the perspective of the 99 religious education teachers on the questions given to them. On the frequency of gender, $57.6 \%$ are female while $42.4 \%$ are all male. On the other hand, majority of the respondent both male and female belong to the $20-35$ age brackets comprising $43.4 \%$, while $33.3 \%$ belong to the $35-49$ age bracket and $19.2 \%$ are within the $50-65$ years of age. Furthermore, $4 \%$ of the total number of respondents belong to above 65 age group. All the respondents were presented with four questions which pertains to their perception of their identity as religion teachers. The respondents were given first an informed consent form prior to the administration of the survey instrument, not just to ask simply for their permission, but more importantly to be ethical in dealing with the information of the respondents, and the data gathered from them by this study.

\section{Result}

Moreover, upon close analysis on their responses and the nature of the questions, the researcher was able to identity three main categories where the answers from the respondents could be organized and better make sense to the intricacies of the said responses. The categories of the responses are intrinsically related to the nature of the questions given. It is good to note that the researcher did not include the complete transcript of the responses in this paper but was able to analyze in an inductive way each response and correlated each one with the other such that the derivative of such correlation is deeply manifested in categorization of the responses. In other words, the identified categories carry with themselves the sense of the respondents' responses. The table below shows the specification of questions, adopted from the unpublished formulation of Dr. Dionco's, as well as the three categories where responses were based.

\section{Table 1}

Specification of Questions and the Category of Responses

\begin{tabular}{lc}
\hline \multicolumn{1}{c}{ Questions } & Category of Responses \\
\hline How to you describe your role as a religious or values educator & Vocation \\
What do you like best about teaching religion or values education? & Rootedness \\
What do you perceive as difficulties or challenges in your work as religious or values & Vocation \\
educator? & Formation \\
What can be done to address your perceived difficulties or challenges? & \\
\hline
\end{tabular}

In analysis, one could stipulate that the Category of Responses - Vocation, Rootedness, and Formation does not only represent the responses of the respondents but also speaks of the very nature of the question. The first question has something to do with the very perception of the respondents' role as religious education teachers. Remarkably, the respondents have a positive perception of their role - being a religious education teacher is not just simply a mere profession nor a job that one needs to fulfill in order to earn something in return, but the role is perceived as a vocation, a ministry of guiding the young towards the realization of the presence of the divine in their life. In other words, being a religious educator means being a mentor, a preacher, and a formator of the faith whose vocation is to "teach minds, touch hearts, and transform lives" (Teehankee, 2014) centered in evangelizing the learners to the authentic, universal, and objective truths of this world which foundation is the ultimate Truth, God alone in Christ (John Paul II, 1993). Therefore, to faithfully adhere to the duties and responsibilities of one's role as a religious education teacher, or better yet to devotedly respond to one's vocation as a religion teacher one must pattern one's very life on the person of Christ, who is his earthly life bore witness to the truth by proclaiming it both in words and in deeds (Benedict XVI, 2009) bringing the people closer to God. Through and with this, the Catholic educator communicates the truth and therefore participates in the mission of Christ. "For the Catholic educator, whatever is true is a participation in Him who is the Truth; the communication of truth, therefore, as a professional activity, is thus fundamentally transformed into a unique participation in the prophetic mission of Christ, carried on through one's teaching" (Sacred Congregation for Catholic Education, 1982, par. 16). The respondents have a clear perception of the role as Religious Education teachers - it is a vocation of bringing the learners to the Truth and of participating in the evangelical mission of 
the Church as well in the prophetic mission of Christ.

Moreover, the respondents argued that such perception of looking at one's role as religion teacher as a vocation takes its roots in the educator's relationship with the person of Jesus. This sense of rootedness (second category) in God through Jesus has an enabling effect that encourages and inspires religious educators to profess their faith and lead others to live the faith. Therefore, the epitome of the vocation as religious education teachers is the educator's very relationship with God. If a religion teacher does not have a strong bond with God, his/her ministry or vocation would easily lose its meaning and substance. Rootedness in God is a requisite element in being an effective witness of the faith (Congregation for Catholic Education, 2002).

However, even if the respondents have a clear understanding of their role as religious educator, it is the same category - vocation that their perception of difficulties and challenges in performing the role is founded. Therefore, the response to the third question has something to do with the manner or mode on how to be an effective religious education teacher, and how to perform their vocation well specifically based on the performance and temperament of the learners in front of the subject; the problem is not on the understanding of the vocation but on the pedagogical approach, methodology, and behavioral dimension in doing the vocation as a religious education teacher. Hence, the problem is multifaceted for it concerns not only the pedagogical and methodological approach in teaching religious education, but also the practical application of its principles when it comes to the behavioral, relational, religious, and moral aspects seen in the life both learners and the educators and the community as well. In order to respond to this problem on the vocation's practical dimension, the respondents pointed out the importance of formation (the third category) as the key to address the issue. The respondents made mention about seminars; integration of values in teacher formation; meaningful revision of the curriculum in Religious Education; having a meaningful spiritual life among teachers. It is in this reason of intervention that the researcher has framed the responses using the Discipleship Process Framework of Lewis, to give a clear sense out of the respondents' responses, but more importantly to present an approach in addressing the issues identified by the respondents and to present a framework to explain in a reasonable way the perception of religious educators regarding their identity.

\section{Discussion}

\subsection{The Discipleship Process}

Dr. Casey Lewis in an article published in Christianity Matters had illustrated the concept of discipleship as a formative process of fortifying not only one's faith in Christ but also the transformative manner of such faith. Lewis (2015) identified five steps in the Discipleship Process:

$>$ Come and Worship = The initial phase of the Discipleship Process where the person has been touched by God in his/her own lived experiences that makes a difference in the way he/she conducts his/her life. The person's very experience to the divine actively working in one's life serves as an unconscious invitation that stirs one's interest to deepen one's knowledge and bond with God. In the usual sense, the person's expresses this disposition through an initial involvement in religious things that would give him/her a sense of familiarity to the incomprehensible character of the divine. In other words, a person has the tendency to know God better through religious worship and affiliation.

$>\quad$ Stay and Connect $=$ The second phase of the process has something to do with remaining connected with the divine and maintaining active involvement with religious activities as forms of expressions. Lewis argued that in order to know God and responded to God's call better, one must stay connected to the object or means of faith; that is to say, one must be in constant communion with God. This stage could also be considered as the formative phase of the Discipleship Process where the one who has been touched by God, undergoes the process of deepening one's knowledge of God by knowing not just the lofty nature of who God is as explicated in the ecclesia nor magisterial teachings of the Church 
(doctrine), but most importantly knowing and doing the ways of the Jesus (moral), and celebrating (worship) the life that this relationship brings.

$>\mathbf{G o}=$ After the person is able to enrich one's knowledge and relationship with God as expressed and actively involving oneself in the three deposits of faith - Doctrine, Moral and worship, the person then would enter the third phase of the Discipleship Process, the commissioning phase. In the commissioning phase the person is sent to impart or share to others the faith (Lewis, 2015) that he/she received from God; allowing others to have an inimitable and personal experience with the divine fully present in the witnessing of the commissioned person. The theologian Roberto Goizueta (2009) argued that a life lived in testimony to the credibility of the Christian kerygma - "More than any abstract principle, dogma, or theological propositions, the concrete lives of the exemplary Christians are what have attracted many to Christ." (p.2). In other words, the life of the commissioned is the crucible of the rich heritage of the Christian faith, for the fullness of the faith in Christ lies not in the loftiness of theological reflections but in the simplicity of the life of the person in witnessing to the very life of Jesus (Francis, 2020). Therefore, the presence of the commissioned must be sacramental radiating the presence of God.

$>\quad$ Serve $=$ The fourth phase has something to do with social responsibility not only of those who were commissioned (referring not necessarily with the ordained but to all faithful who had received the faith and chose to enrich it through either an active involvement in the Church, or a life of service centered in proclaiming the message of Christ) but also those who had received the message of faith in the person of Christ. In other words, to have faith in Christ is to have a strong sense of shared responsibility of serving one another especially the marginalized. Lewis argued that if the faithful take the prospect to serve the Church by the virtue of the faith in Christ this could lead to the ever flourishing of faith and the community disciples (Lewis, 2015).

$>\quad$ Bring others along $=$ The final stage in Lewis' Discipleship Process has something to do with making disciples out of those who has witnessed the faith of the disciples. It is by bringing others to the source of faith, Christ himself, could one as a disciple be able to be true to the vocation that one's very faith entails. Moreover, it is in this final phase of the process that a disciple fulfills the mandate of Jesus during the Ascension scene (see Matthew 28:19) allowing others not only to experience God in the simplicity of their life but transforming them to be disciples themselves. Therefore, faith in God makes a community of disciples.

\subsection{The appropriation of the discipleship process with the context of the respondents}

If one will take a close look and analysis on the process of Discipleship Process of one could clearly see the relevance of such process in the context of the respondents' view of their identity as religious educators as well as its corresponding challenges. The Discipleship Process helps a person understands better the context of the respondents in a systematic way. Therefore, this section of the study is apportioned to contextualize Lewis' Discipleship Process as a framework in assessing the respondents' perception on their identity as religious educators. The framework demarcates the identity as a religious education teacher as an identity of discipleship where one has a noble vocation of proclaiming the message of Christ and transforming those who receives such proclamation after the image of the one being proclaimed. It is in this sense that to be a religious educator is to be a disciple, and to be a disciple is to take on oneself the duty to teach the faith in the spirit of discipleship. The illustration below shows how the categories were appropriated in the Discipleship process forming the very framework of the Discipleship Identity of Religious Educators. 


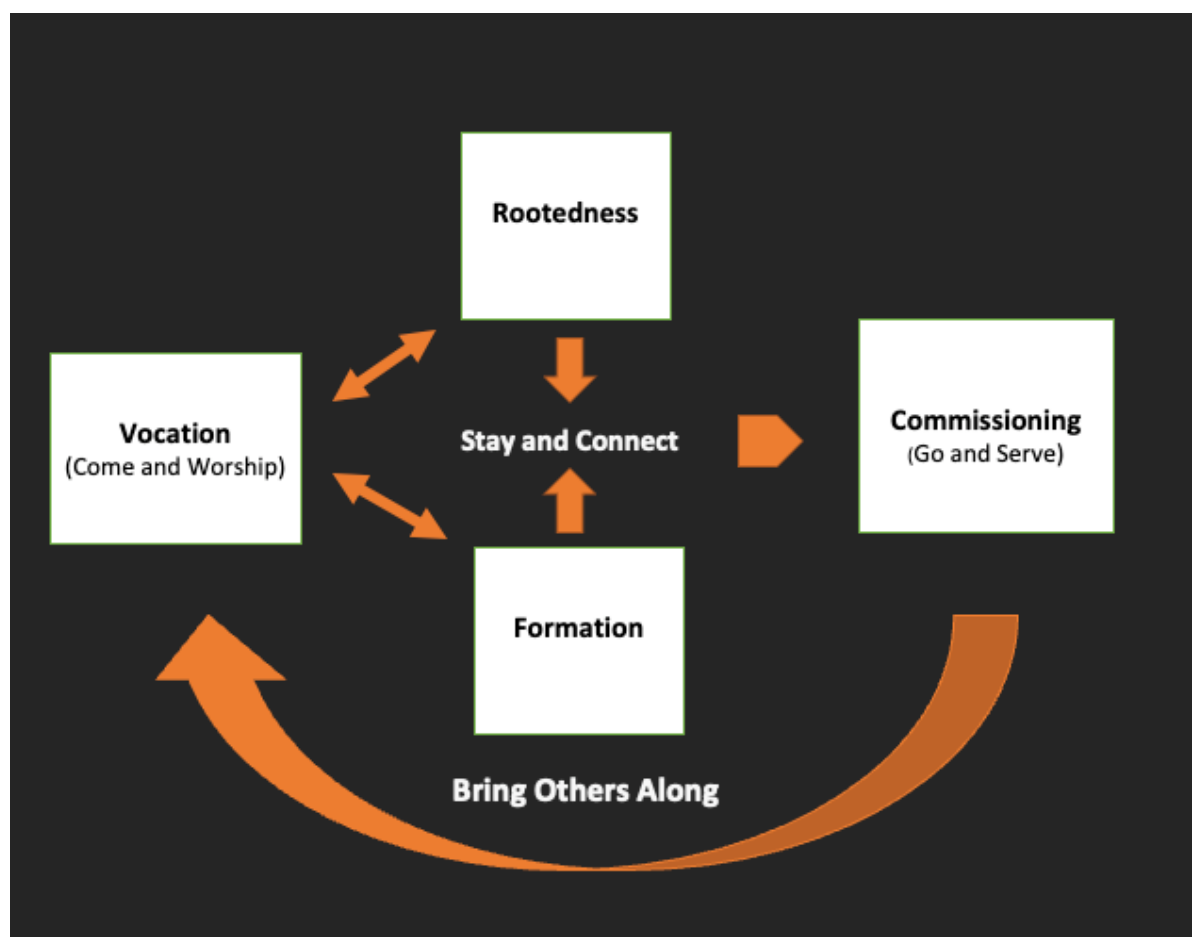

Illustration 1. Discipleship Identity of Religious Educators Framework (DIREF)

The framework on the Discipleship Identity of Religious Educators (DIREF) illustrates and reflects the responses of the respondents that being a religious educator is a vocation from God, a kind of identity which God has called one to become - a mentor, formator, preacher, evangelizer, and a teacher to the young. Through this God given identity a religious educator shares in the mission of Christ (Paul VI, 1975), and more importantly bears Christ himself manifested in one's proactive witnessing of the faith (Sacred Congregation for Catholic Education, 1982). That is why the first stage of the framework starts with the first category which is Vocation whereby the person has a full knowledge and is conscious about the workings of the divine in one's life and has a clear picturesque on the nature of the teaching profession especially in the case of religious education teachers. The respondents are clear that to be religious educator is to vest oneself with the identity of Christ who first called the former to be the latter's hands, feet, and mouth to the young - Christ calls and the one who has been called responded to be a religious education teacher.

On the other hand, theme that would summarize the problems and challenges that the respondents saw in manifesting effectively their role and identity as religious educators is the necessity for an ongoing formation to enrich their pedagogical approach in presenting the topics to the students as well as a relevant updating of the content of instruction and the curriculum for Religious Education. Moreover, the respondents' places incomparable amount of importance as part for their ongoing formation the deepening of their faith through various religious activities. It is this regard that the second phase of the DIREF captures the two other categories in the responses of the participants. The two categories should not be comprehended apart from the fist category for they supply the answer to the problem, challenges, and difficulties in animating such vocational identity as religious educators. The category of Rootedness affirms the category of Formation as a form of staying connected to one's identity as an educator the general sense of the term, and as a religious one in a sense. Rootedness in one's identity as an educator entails not just simply knowing the ethical dimension of the identity that normally is the basis of the sense of professionalism of the teaching profession, but part of the professional development is having differentiated programs that could enhance the mastery of teachers over the subject matter along with the constant updating of the new pedagogical approach and theories in teaching (Van Veen et al., 2011). This is the essence of Rootedness in one's identity as an educator intrinsically connected with the formation of the self as a professional teacher. Moreover, in the case of a religious education teacher, one is 
mandated by the nature of one's vocation to be rooted in one's identity as a religious educator - to be rooted not only as a professional teacher but to the source of vocation of being a religious educator who is no other than the divine. Therefore, the formation of religion teachers must primarily and fundamentally be centered on deepening one's relationship with God in the person of Jesus - to stay and connect with God is to stay and connect with one's very identity as religious education teachers (Congregation for Catholic Education, 1988). Hence, flourishing in instruction, pedagogy, and spirituality is the epitome in addressing the challenges and difficulties identified by the respondents in animating their vocation as religious education teachers.

The final phase of the DIREF is the commissioning phase where the person is being sent to impart what one learns from one's formation to others. In the context of religious education teachers, the Commissioning part refers to the concretization of the teaching vocation to the learners, where the religion teacher imparts to the learners the product of his/her own formation in the faith through the different effective ways and means in delivering the faith - "The Gospel must be proclaimed by witnesses" (Paul VI, 1975). Through the proclamation of the faith by the religious education teachers both in the actual teaching and in the practical witnessing of the faith, the teacher evangelizes the learners and his/her own self. Therefore, the religion teacher brings the learners to the realization of the existence of the divine in their own context. The mission of the vocation to the life of being a religion teacher is to bring closer the learners to God - growing more their love and knowledge of God. The commissioning phase of the framework envisions that through the formation, witnessing of the faith, and teaching practice the learners will know God clearly; love God dearly; follow God nearly as what the popular proverb says. The entire sense of the commissioning part is manifested in transforming learners from being strangers into close friends and disciples of Jesus; discipleship is the fruit of the framework - bringing others along with one's journey in knowing, loving, and following God. Therefore, the entire framework is centered indeed on the making oneself and other disciples of the Lord.

\section{Conclusion}

Being a religious education teacher is not an easy task for it speaks of oneself not simply as a professional educator, but more importantly as someone who is called to a vocation and a way of life in manifesting one's faith in God through the teaching platform. It entails, therefore, a lot of formation in order to develop not only one's technical skills as an educator but also one's spirituality as a man of God and a follower of Jesus. The extensiveness of the formative process gives a viable solution to various struggles that a religious educator might encounter in answering the duties and responsibilities attached to one's vocation in proclaiming the Gospel through teaching, forming a sacred space for learners to have a transformative encounter with God. The DIREF ascertains that being a religion teacher is a discipleship identity of making other disciples.

\section{References:}

Benedict XVI. (2009, June 29). Caritas in Veritate. Vatican. Retrieved January 6, 2022, from https://www.vatican.va/content/benedict-xvi/en/encyclicals/documents/hf_ben-xvi_enc_20090629_carit as-in-veritate.html

Buckle, J. (n.d.). A Comprehensive Guide to 21st Century Skills. Panorama Education I Supporting Student Success. Retrieved December 28, 2021, from https://www.panoramaed.com/blog/comprehensive-guide-21st-century-skills

Congregation for Catholic Education. (1988, April 7). The Religious Dimension of Education in Catholic School. Vatican. Retrieved January 11, 2022, from https://www.vatican.va/roman_curia/congregations/ccatheduc/documents/rc_con_ccatheduc_doc_1988 0407_catholic-school_en.html

Congregation for Catholic Education. (2002, October 28). Consecrated Persons and their Missions in Schools: Reflections and Guidelines. Vatican. Retrieved January 6, 2022, from https://www.vatican.va/roman_curia/congregations/ccatheduc/documents/rc_con_ccatheduc_doc_2002 1028 consecrated-persons_en.html 
On being a religious education teacher: A reflection on discipleship identity

Crosswell, L., \& Beutel, D. (2017). 21st century teachers: how non-traditional pre-service teachers navigate their initial experiences of contemporary classrooms. Asia-Pacific Journal of Teacher Education, 45(4), 416-431. https://doi.org/10.1080/1359866x.2017.1312281

Denzin, N. K., \& Lincoln, Y. S. (2017). The SAGE Handbook of Qualitative Research (2nd ed.). SAGE Publications.

Francis. (2020, April 25). Faith must be transmitted, it must be offered, above all by witness. Vatican. https://www.vatican.va/content/francesco/en/cotidie/2020/documents/papa-francesco-cotidie_20200425 _testimoniare-lafede-conlavita.html

John Paul II. (1993, August 6). Veritatis Splendor (6 August 1993) | John Paul II. Vatican. Retrieved January 5, 2022, from https://www.vatican.va/content/john-paul-ii/en/encyclicals/documents/hf_jp-ii_enc_06081993_veritatissplendor.html

Lewis, C. (2015, July 29). What might a church's discipleship process look like? Christianity Matters. https://christianitymatters.com/2015/01/19/what-might-a-churchs-discipleship-process-look-like/

Marenus, M. (2020, June 9). Gardner's Theory of Multiple Intelligences. Study Guides for Psychology Students Simply Psychology. Retrieved December 28, 2021, from https://www.simplypsychology.org/multiple-intelligences.html

Nations, J. E. (1962, November). The Teacher as a Person. Educational Leadership: Continuing for the Teacher, 20(2), 101-104.

Paul VI. (1965, October 28). Gravissimum Educationis. Vatican. Retrieved December 28, 2021, from https://www.vatican.va/archive/hist_councils/ii_vatican_council/documents/vat-ii_decl_19651028_grav issimum-educationis_en.html

Paul VI. (1975, December 8). Evangelii Nuntiandi. Vatican. Retrieved December 28, 2021, from https://www.vatican.va/content/paul-vi/en/apost_exhortations/documents/hf_p-vi_exh_19751208_evan gelii-nuntiandi.html

Prince, M., \& Felder, R. (2007, March/April). The Many Faces of Inductive Teaching and Learning. Journal of College Science Teaching, 36(5), 14-20.

Sacred Congregation for Catholic Education. (1977, March 19). The Catholic School. Vatican. Retrieved December 28, 2021, from https://www.vatican.va/roman_curia/congregations/ccatheduc/documents/rc_con_ccatheduc_doc_1977 $\underline{0319 \text { catholic-school_en.html }}$

Sacred Congregation for Catholic Education. (1982, October 15). Lay Catholics in School: Witnesses to Faith. Vatican. Retrieved January 6, 2022, from https://www.vatican.va/roman_curia/congregations/ccatheduc/documents/rc_con_ccatheduc_doc_1982 1015 lay-catholics_en.html

Teehankee, J. C. (2014, March 28). The La Sallian Way. The LaSallian. Retrieved January 5, 2022, from https://thelasallian.com/2012/10/26/the-la-sallian-way/

Van Veen, K., Zwart, R., \& Meirink, J. (2011). What Makes Teacher Professional Development Effective? A Literature Review. In Teacher Learning That Matters (1st ed., pp. 3-21). Routledge. 
Canete, J. J. O. 